\title{
MONITORING OF PATIENTS' FALLS IN HEALTHCARE FACILITIES
}

\author{
Marcela Ižová ${ }^{1}$, Michaela Vicáňová ${ }^{2}$, Mária Novysedláková ${ }^{3}$
}

\begin{abstract}
:
INTRODUCTION: The issue of hospitalized patients' falls in healthcare facilities should be one of the most essential interests of healthcare employees. Monitoring, keeping of records and the assessment of the documentation related to the occurrence of patients' falls in a healthcare facility helps healthcare employees determine the frequency of falls. Monitoring of extraordinary events helps identify weaknesses in patient care and point out recurring issues, which influence the quality and safety of the provided care. A reduction in the number of falls in every healthcare facility requires a complex approach of healthcare employees, which includes admitting, assessing, and reducing the risks of falls.

OBJECTIVES: The aim of this report was to point out the occurrence of hospitalized patients' falls in a healthcare facility.

METHODS: The data collection was done through a survey method (unstandardized survey). The research group was composed of nurses $(n=130)$ providing nursing care to patients in four healthcare facilities in Trebišov, Vranov nad Topl'ou a Michalovce. The average age of the nurses was 38.7 years old. The results were analyzed through absolute and relative frequency. The Chi-squared test was used as a statistical method. The obtained results were interpreted on the significance level $\alpha=0.05$. The sorting criteria included age, type of department, and level of experience.

RESULTS: The obtained results point out that nurses use conversation and observation to assess the risk of patients' falls. In the research sample, falls occur with an increased incidence. There is a statistically significant contrast $(p=0.02)$ concerning the way in which nurses in each department report falls.

CONCLUSION: In the issue of falls, nursing documentation plays a big role because falls are documented as extraordinary events. Based on our results, we suggest using a unified, standardized tool to assess the risk of falls in healthcare facilities, as monitoring extraordinary events can influence the quality and safety of the provided nursing care.
\end{abstract}

UDC Classification: 614.8 , DOI: 10.12955/cbup.v7.1449

Keywords: monitoring, falls, measurement tools, nurses, documentation

\section{Introduction}

Patient safety is defined as the prevention of undesirable events during the period of providing healthcare with the aim to minimalize harm of the patient and achieve safer healthcare, and the right of the patient to not be caused harm or potential harm connected to constitutional healthcare BSH (2014). It is estimated that $8-12 \%$ of hospitalized patients in EU member states are exposed to undesirable events while being provided healthcare (Conklin, 2009). Multiple authors, Hughes (2008), Aspden, et al. (2004), define patient safety as the prevention of making mistakes and harming the patient and reducing the risk of undesirable events. They emphasize learning from mistakes and building a culture of safety in the healthcare system, which includes organizations, professionals, and patients. According to The Agency for Healthcare Research and Quality, and The Joint Commission, nurses play a key role in ensuring quality healthcare and patient safety (AHRQ, 2019; The Joint Commission, 2010). Monitoring of the number of falls and injuries is one of the indicators of quality of the offered healthcare. In contrast with other EU countries, the Slovak Republic is still missing a complex program for the monitoring and prevention of falls including a multifactorial assessment, interventions, and a training program for healthcare employees and patients. Official statistical data about the number of patients' falls, subsequent injuries, or eventual death as a result of a fall are not commonly available to the professional public in Slovakia, so data from various international sources is often mentioned (Bóriková and Tomagová, 2016; Bóriková et al., 2019). Within the EU, the occurrence of falls is often monitored in relation to the hospitalization of the elderly and in the years 2000 to 2010, 35,000 out of 40,000 falls have resulted in death (Božidar, 2016). Among the most frequent causes of patients' falls in healthcare facilities are mistakes of employees, inadequate patient supervision, incorrect evaluation of the risk of falling, or an incorrect diagnosis. The issue of patients' falls should be an essential interest of an organization as a way to improve its internal culture. According to Dostálová and Nahodilová, (2011) a fall can be defined as a patient's sudden and unexpected descent from a standing, sitting, or horizontal position, including slipping off a chair and including an assisted fall when an individual leads the patient to the ground, with or without injuring the patient. The main consequences of patients' falls are various injuries (eg. fractures, subdural

\footnotetext{
${ }^{1}$ Faculty of Health, Catholic University in Ružomberok, Ružomberok, Slovakia, marcela.izova@ku.sk

${ }^{2}$ Faculty of Health, Catholic University in Ružomberok, Ružomberok, Slovakia, michaela.vicanova@ku.sk

${ }^{3}$ Faculty of Health, Catholic University in Ružomberok, Ružomberok, Slovakia, maria.novysedlakova@ku.sk
} 
haematoma), which complicate the basic illness, require further treatment, prolong the hospital stay, increase additional costs of care, or even lead to a law suit for inadequate care. The length of the hospital stay as a result of falls varies, but it is significantly longer than in other cases and it ranges from 4 to 20 days (World Health Organization, 2007, p. 2). Activities, which may be connected to the issue of patients' falls include assessment of their needs and levels of independence, evaluation of their symptoms, and evaluation of risk factors using monitoring techniques in nursing (Šupínová, 2013).

The aim of this report is to point out the occurrence of hospitalized patients' falls in a healthcare facility.

\section{Methods}

This research has the characteristics of a cross-sectional study. An important role of healthcare employees is to ensure a safe environment for a patient. The first area of the survey served to find out whether nurses working in a healthcare facility assess the risk of falling when admitting a patient. The second area of the survey was focused on the documentation of the occurrence of falls and injuries in patients in a healthcare facility. The data collection was done through a survey method (unstandardized self-constructed survey). The surveys were distributed with the agreement of the ethical commission of the healthcare facility through head nurses. The survey included 30 items, 3 of which were demographic questions and 27 of which were research questions. In total, we distributed 200 surveys (we received 130 filled surveys, return rate 65\%). The basic set was comprised of nurses $(n=130)$, who provide care to hospitalized patients in surgical departments (surgical, traumatology department) and internal medicine departments (internal, neurological, psychiatric, and long-term department) in hospitals in Trebišov, Vranov nad Toplou, and Michalovce. Results obtained by the survey method were analyzed through absolute and relative frequency. Based on the survey items, we created a database structure, in which we put in respondents' responses through chosen coding. For the purpose of a descriptive evaluation, we used mathematical and statistical functions. For the purpose of analysis - determination of the statistical significance of the differences in responses in subgroups created according to sorting characteristics (age, type of department, and level of experience), we used the Chi-squared test. The obtained results were interpreted on the significance level $\alpha=0.05$. The nurses' age ranged from 20 to 60 years old, the average age of respondents was 38.7 years old and the average length of experience was 19.8 years. We consider it important to warn you that the choice of the sample was not randomized. In consideration of this, we cannot generalize the results of this study to the whole population of nurses, they are only valid in this respondent sample.

\section{Results}

The majority of nurses (54\%) in the researched sample had more than 15 years of clinical experience, the second largest group (20\%) was comprised of nurses with less than 5 years of clinical experience and the two smallest groups were nurses with 6-15 years of clinical experience, both groups included $13 \%$ of nurses. Talking to the patient is considered important by 107 (82\%) nurses and 68 (53\%) nurses also consider talking to the patient's relatives important. Assessment scales are used by 17 $(13 \%)$ of nurses. From the analysis of the Chi-squared test $(p=0.00)$, we can see that nurses apply on a significantly higher statistical level, when determining the risk of a patient's fall, talking to the patient, talking to the patient's relatives, and observation. We can then state that assessment scales and study of documentation are used on a significantly lower statistical level. Results are presented in Table 1.

From a set of 130 nurses, $60 \%$ of nurses do not use assessment scales and $27 \%$ of nurses use the Barthel test. Functional Gait Assessment is used by 5\% of nurses and 6\% of nurses use the 'Timed Up and Go' test to assess the risk of falling. The Morse Fall Scale is only used by $2 \%$ of nurses.

We researched the occurrence of falls in healthcare facilities. Nurses in $115(88 \%)$ cases reported the occurrence of a fall as an extraordinary event in their workplace. An absence of falls during their experience was reported by $15(12 \%)$ nurses. The most frequent causes of a patient's fall (only answered by nurses who reported a patient's fall) are written in Table 2.

Nurses who chose the semi-open answer "other" reported restlessness and disorientation as the most frequent cause of falls. 


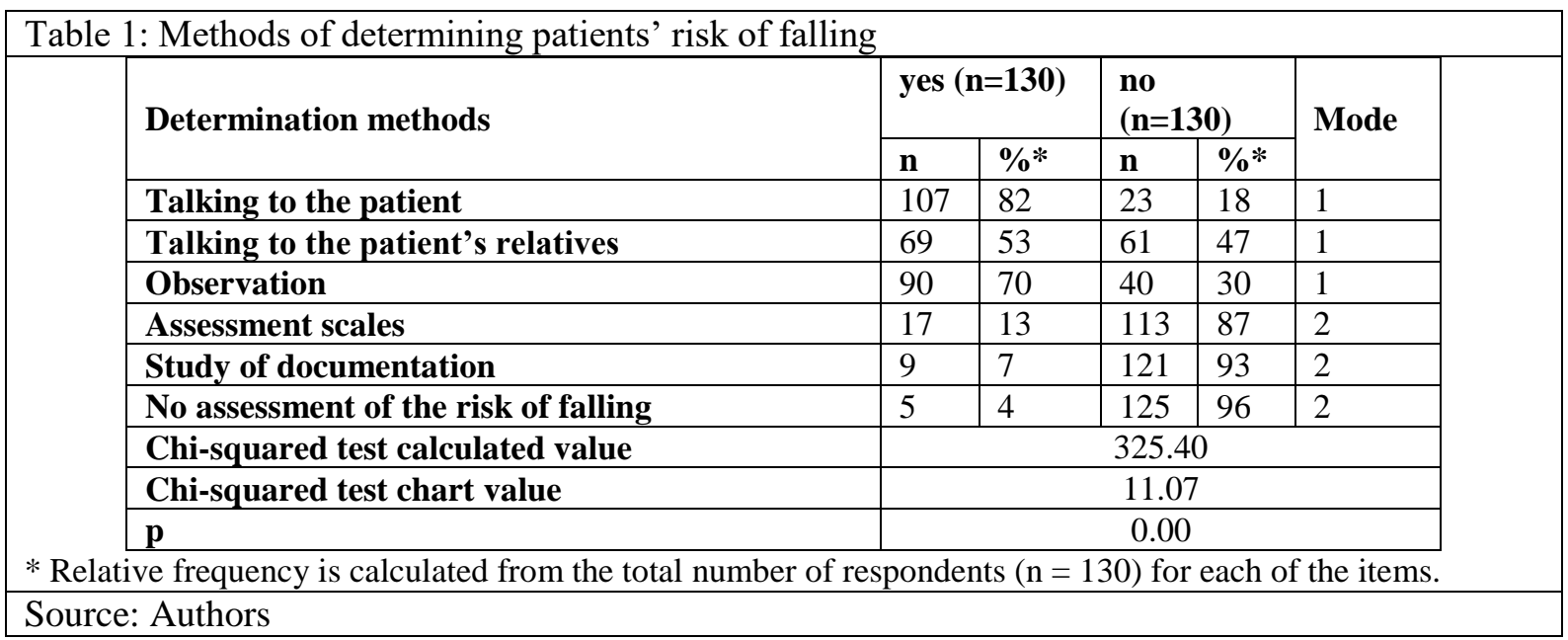

Table 2: The most frequent cause of falls

\begin{tabular}{|l|c|c|}
\hline \multirow{2}{*}{\multicolumn{1}{c|}{ Cause of falls }} & \multicolumn{2}{c|}{ amount } \\
\cline { 2 - 3 } & $\mathbf{n}$ & \%* $^{*}$ \\
\hline Acute diseases & 29 & 25 \\
\hline Disease of the musculoskeletal system & 41 & 35 \\
\hline Vision malfunctions & 4 & 4 \\
\hline Orthostatic hypotensions & 10 & 9 \\
\hline Unknown & 29 & 25 \\
\hline Other & 2 & 2 \\
\hline
\end{tabular}

* The relative frequency is calculated from the number of respondent responses $(\mathrm{n}=115)$ for each item.

Source: Authors

We also researched what kind of patients' falls are most common. Out of all nurses in our study, $27 \%$ think that the most common fall is by tumbling, 34\% reported tripping, and 36\% of nurses reported slipping.

Via our survey, we monitored the consequences of patients' falls in a healthcare facility. $46 \%$ of nurses recorded a graze as a consequence of a fall in a healthcare facility, $26 \%$ of nurses reported a lacerated wound, and $22 \%$ of nurses recorded a fracture.

Out of all the nurses, $79 \%$ said they always report a fall, $15 \%$ only do it sometimes. $36 \%$ of nurses announce an extraordinary event to the head nurse, $52 \%$ announce it to a doctor, $8 \%$ announce it to the head of the department. We also researched the way nurses report a fall in their department. Based on our analysis, $53 \%$ of nurses report it through a free form, $37 \%$ of nurses report it through a specific form.

\begin{tabular}{|c|c|c|c|c|c|c|c|c|c|c|c|c|}
\hline \multirow{2}{*}{$\begin{array}{l}\text { Announcement of } \\
\text { a fall/injury }\end{array}$} & \multicolumn{2}{|c|}{ Surgery } & \multicolumn{2}{|c|}{ Traumatology } & \multicolumn{2}{|c|}{ Internal } & \multicolumn{2}{|c|}{ Neurology } & \multicolumn{2}{|c|}{ Long-term } & \multicolumn{2}{|c|}{ Psychiatry } \\
\hline & $\mathbf{n}$ & $\% *$ & $\mathbf{n}$ & $\% *$ & $\mathbf{n}$ & $\% *$ & $\mathbf{n}$ & $\% *$ & $\mathbf{n}$ & $\% *$ & $\mathbf{n}$ & $\% *$ \\
\hline To the head nurse & 10 & 39 & 7 & 34 & 15 & 65 & 8 & 26 & 0 & 0 & 6 & 43 \\
\hline To a doctor & 14 & 53 & 11 & 52 & 8 & 35 & 17 & 54 & 12 & 80 & 7 & 50 \\
\hline $\begin{array}{l}\text { To the head of the } \\
\text { department }\end{array}$ & 1 & 4 & 3 & 14 & 0 & 0 & 3 & 10 & 3 & 20 & 1 & 7 \\
\hline No announcement & 1 & 4 & 0 & 0 & 0 & 0 & 3 & 10 & 0 & 0 & 0 & 0 \\
\hline $\mathbf{n}$ & 26 & 100 & 21 & 100 & 23 & 100 & 31 & 100 & 15 & 100 & 14 & 100 \\
\hline $\begin{array}{l}\text { Chi-squared test } \\
\text { calculated value }\end{array}$ & \multicolumn{12}{|c|}{28.33} \\
\hline $\begin{array}{l}\text { Chi-squared test } \\
\text { chart value }\end{array}$ & \multicolumn{12}{|c|}{25} \\
\hline $\mathbf{p}$ & \multicolumn{12}{|c|}{0.02} \\
\hline
\end{tabular}


The result of the Chi-squared test $(\mathrm{p}=0.02)$ shows a statistically significant difference in the method of announcing the fall in various departments. In all of the observed departments, besides the internal department, the majority of nurses announces the fall to the doctor. In the internal department, a significant majority of nurses announce falls to the head nurse (Table 3 ).

\section{Discussions}

When admitting a patient to a department, it is necessary for nurses to assess their risk of falling. According to Vörösová (2011), an important part of the implementation of the nursing process method is evaluating the needs of the individual, the family, and the community. When assessing the patient's issues in the area of biological needs in clinical practice, nurses use assessment scales, in addition to basic methods, such as observation and talking to the patient. These assessment scales allow them to objectify a patient's data and bring global and holistic results. 50\% of nurses always assess the risk of falling when admitting a patient, while $45 \%$ of nurses only do it sometimes. In the Slovak nursing practice, there is no standardized procedure of identification of patients with a higher risk of falling, including the usage of a valid measurement tool. That is why it is possible to use the most tested tool as a standardized valid tool to identify the patient's risk of falling, like the Morse Fall Scale 17-20 or the Hendrich II Fall Risk Model 2 (Bóriková et al., 2017, AHRQ, 2013). The legislative norm in Slovakia only includes a brief general protocol of assessing the risk of falling, the recommended tool is absent (Bóriková and Tomagová, 2016). Assessment of the risk of falls through the history of risk factors, screening, and an in-depth analysis of specific risk factors is key for their identification (Bóriková and Tomagová, 2016). The methods which nurses use for finding out the risk of falling can be an issue. The first step in the identification of a risk of falling is assessing the patient through an assessment tool, which the nurse is able to use. The results of our research show a low frequency of using a screening assessment tool in 17 nurses (13\%). According to Graham (2012), more tools can be used. Authors Fonad et al. (2008) also directly recommend the realization of risk assessment through various screening scales. Jurásková (2007) states that a patient's relatives play an important role in assessing the risk of falling, especially with patients, who are not able to communicate or answer questions. In Ulrichová's research (2012), 37 out of 86 nurses used the Barthel test while assessing the risk of a patient's fall in a healthcare facility. The Functional Gait Assessment was only used by 5 nurses. 20 nurses preferred the 'Timed Up and Go' test. According to Morse (2002), 14\% of falls in healthcare facilities are random, $8 \%$ are unexpected, and the rest are expected physiological falls. Screening of the risk of falling is supported by multiple studies AGS (2010), Basran et al. (2013), Degelau, et al. (2012) as an effective method for finding individuals prone to falling. The selection of a standardized and reliable tool is not an easy decision, as head employees of a healthcare organization must consider the difficulty of use, the training of staff, psychometric characteristics (validity and reliability), possible adoption and adherence of the staff, and other factors (Haines et al., 2006). Even legislative norms, such as the Proclamation of the Ministry of Health of the Slovak Republic 95/2018 Z.z. (MHSR, 2018), dictate the application and innovation of assessment scales and tools used in nursing practice. We assess the risk of a patient's fall when they are admitted to the department or when their health condition changes. The nurse uses tests and scales to objectively assess the risk in this case as well. Gray-Miceli (2012) describes a connection between falls and specific types of departments. The departments with the most falls are the ones, where the provided care is long-term and provided to geriatric patients - the higher the age, the higher the occurrence of falls. According to Krajčík (2006), falls are the most common cause of injuries, which are the fifth most common cause of death in old people.

It is necessary to document and announce the occurrence of all extraordinary events in nursing care. If a patient falls in a healthcare facility, it is important that the fall/injury is recorded. In modern healthcare, announcing extraordinary events is an important educational element, as well as crucial feedback that is needed for corrective measures in the system, which made the extraordinary event possible (Škrla, 2005, p. 22). The majority of nurses (79\%) in our research always report a patient's fall and they usually report it to a doctor (52\%). Healthcare employees report accidents or accidental infractions on the standard protocols, which are approved by the leadership of constitutional healthcare facilities (BSH, 2014). Announcement systems are implemented by healthcare providers as a part of the strategy of a patient's safety within ensuring quality in accordance with $\S 9$ of Act 578/2004 Z.Z (NCSR, 2004). Every healthcare facility develops two announcement systems, which take into account 
the type of healthcare facility and its organizational structure. These announcement systems will stem from the announcements of employees as a system of voluntary announcements and a system of mandatory announcements (BSH, 2006). The most important function of announcement systems is the inquiry, analysis, and usage of the data to improve constitutional healthcare and support healthcare employees to do their job in a safer way BSH (2014). Irrespective of the type of healthcare facility, the head employees must ensure that the assessment and reassessment of each patient from the perspective of the risk of falling is part of the team assessment process. An interdepartmental group can evaluate how clinical and environmental factors affect the risk of falling and determine measures for lowering this risk. It controls the state of cognitive functions and determines the effect of treatment on the patient's ability to behave safely in the given environment and to follow recommendations. The duties of each team member should be clearly defined in a formal document (Vyhnánek, 2007, p. 62).

\section{Conclusion}

We consider patients' falls an undesirable event and their frequency is monitored in some healthcare facilities, as falls are one of the indicators of the quality of the provided healthcare. To identify the risk levels, it is important to establish a unified system of standardized and lasting fall risk assessment in organizations (hospitals, nursing units) (Ganz et al., 2013, Gray-Miceli and Quigley, 2012). It would be appropriate to use a standardized, validated tool, such as the Morse Fall Scale17-20 for monitoring and assessment of the risk factors of falling, which would be integrated into the electronical health record (AHRQ, 2013). The monitoring of extraordinary events helps identify weaknesses in patient care and point out recurring issues, which influence the quality and safety of the provided care. As long as the mistakes of healthcare employees are reported, it is possible to analyze situations that lead to extraordinary events and initiate changes that will lead to their elimination (Líšková \& Starovičová, 2012).

\section{References}

AGS, American geriatrics society and british geriatrics society. (2010). Clinical practice guideline for the prevention of falls in older adults. New York. Retrieved from American Geriatrics Society:

http://www.alabmed.com/uploadfile/2014/0504/20140504033204923.pdf

AHRQ Agency for Healthcare Research and Quality. (2013, January 20). Tool 3H: Morse Fall Scale for Identifying Fall Risk Factors. Retrieved máj 20, 2018, from Preventing Falls in Hospitals:

https://www.ahrq.gov/professionals/systems/hospital/fallpxtoolkit/fallpxtk-tool3h.html

AHRQ Agency for Healthcare Research and Quality. (2019, January). Nursing and Patient Safety. Retrieved from Patient Safety Primer: https://psnet.ahrq.gov/primers/primer/22/nursing-and-patient-safety.

Aspden, P., Corrigan, J. M., Wolcott, J., \& Erickson, S. M. (2004). Patient Safety: Achieving a new standard for Care. Commitee on Data Standards for Patient Safety. Washington, D.C.: The National Academies Press. Institute of Medicine of the National Academies.

Basran, J., Bernier, P., Davis, D., Dusek, B., Feldman, F., Fraser, K., ... Wagner, L. M. (2013, June 2). Reducing falls and injuries from falls. Retrieved november 20, 2018, from The Registered Nurses' Association of Ontario for preparing the Fall Prevention/Injury Reduction, The Canadian Patient Safety Institute (CPSI):

https://www.patientsafetyinstitute.ca/en/toolsResources/Documents/Interventions/Reducing\%20Falls\%20and\%20Injury\%20f rom\%20Falls/Falls\%20Getting\%20Started\%20Kit.pdf

Bóriková, I., \& Tomagová, M. (2016). Pády u hospitalizovaných pacientov-posudzovanie rizika. [Falls in hospitalized patients - risk assessment]. Retrieved from Ošetrovatel'stvo: teória, výskum, vzdelávanie. [Nursing: theory, research, education]: http://www.osetrovatelstvo.eu/_files/2016/01/26-pady-u-hospitalizovanych-pacientov-posudzovanie-rizika.pdf

Bóriková, I., \& Tomagová, M. (2016). Posudzovanie rizika pádu u hospitalizovaných pacientov - komparatívna štúdia [Assessment of the risk of falling in hospitalized patients / comparative study]. Ošetřovatelský výzkum a praxe založená na důkazech - sborník př́spěvků z X. mezinárodního sympozia ošetřvatelství [Nursing Research and Practice Based on Evidence - Almanac from the X. International Nursing Symposium] (pp. 16-17). Ostrava: Ostravská univerzita v Ostravě, Lékařská fakulta [University of Ostrava, Faculty of Medicine].

Bóriková, I., Tomagová, M., \& Miertová, M. (2019). Pády a ich prevencia u hospitalizovaných pacientov. [Falls and their prevention in hospitalized patients]. Martin: Osveta. [Enlightenment].

Bóriková, I., Tomagová, M., Miertová, M., \& Žiaková, K. (2017). Stupnica rizika pádu podl’a Morse Fall Scale [Scale of the risk of falling according to the Morse Fall Scale]. Teória, výskum a vzdelávanie v ošetrovatel'stve - Zbornik z vedeckej konferencie [Theory, Research, and Education in Nursing - Almanac from a Scientific Conference] (pp. 22-23). Martin: Univerzita Komenského v Bratislave, Jesseniova lekárska fakulta v Martine, Ústav ošetrovatel'stva [Comenius University in Bratislava, The Jessenius Faculty of Medicine in Martin, Department of Nursing].

Božidar, V. (2016, January). Public-Health importance of falls in the elderly - Active and Healthy Ageing for Active and Healthy Old Age -. Retrieved from Aktivno in zdravo staranje v Sloveniji [Active and healthy aging in Slovenia]: http://www.staranje.si/sites/www.staranje.si/files/upload/images/analitsko_poro_ilo3-padci-ang_1.pdf 
BSH Bureau of Supervision of Healthcare. (2006, oktober 25). Metodické usmernenie č.7/2006 o zavádzani systémov hláseni $v$ ústavnej starostlivosti... [Methodical regulation n.7/2006 about implementation of announcement systems in constitutional care within the strategy of a patient's safety]. Retrieved december 20, 2018, from Úrad pre dohl'ad nad zdravotnou starostlivost'ou [Bureau of Supervision of Healthcare]: http://www.udzs-

sk.sk/documents/14214/30326/MU_7_2006_o_hlaseniach_25_10_06.pdf/80b0acc8-1e1e-4b6a-bcaf-707254928c93

BSH Bureau of Supervision of Healthcare. (2014). Metodické usmernenie č.3/2014 o zavádzaní systémov hlásení chýb, omylov a nežiaducich udalostí v ústavnej .... [Methodical regulation n.3/2014 concerning systems for announcing mistakes and undesirable situations in constitutional healthcare]. Retrieved from Úrad pre dohl'ad nad zdravotnou starostlivost'ou na Slovensku. [Healthcare Surveillance Authority in Slovakia]: http://www.udzs-

sk.sk/documents/14214/19493/MU+\%C4\%8D.+3-

2014+o+zav\%C3\%A1dzan\%C3\%AD+syst\%C3\%A9mov+hl\%C3\%A1sen\%C3\%AD+ch\%C3\%BDb+omylov+a+ne \%C5\%B Eiaducich+udalost\%C3\%AD+v+\%C3\%9AZS_web.pdf/2ccc1c3e-bdd9-4380-8298-f1de065e0a89

Conklin, A. (2009). Room for improvement; Strong patient safety systems could limit health, social and economic harms from medical error. Retrieved from RANDEurope: http://www.rand.org/pubs/research_briefs/2009/RAND_RB9472.pdf Degelau, J., Belz, M. B., Bungum, L. D., Flavin, P. L., Harper, C., Leys, K., . . Webb, B. (2012, April 10). Institute for Clinical Systems Improvement. Prevention of Falls (Acute Care). Retrieved máj 20, 2018, from ICSI Institute for Clinical Systems Improvement:

https://webcache.googleusercontent.com/search?q=cache:XZ4DgwfFZ3wJ:https://iu.instructure.com/courses/1491754/files/5 6997226/download\%3Fwrap\%3D1+\&cd=1\&hl=sk\&ct=clnk\&gl=sk

Dostálová, B., \& Nahodilová, H. (2011). Prevence pádu ve zdravotníckem zařizení [Prevention of falls in a healthcare facility]. Sestra [Nurse](1), 31-32.

Fonad, E., Wahlin, T.-B. R., Winblad, B., Emami, A., \& Sandmark, H. (2008). Falls and fall risk among nursing home residents. Journal of Clinical Nursing(1), 126-134.

Ganz, D. A., Huang, C., Saliba, D., Shier, V., Berlowitz, D., Lukas, C. V., . . Neumann, P. (2013, January). Preventing falls in hospitals: a tookit for improving quality of care. Retrieved from Agency for Healthcare Research and Quality, AHRQ Publication: https://www.ahrq.gov/sites/default/files/publications/files/fallpxtoolkit.pdf

Graham, B. C. (2012, September/October). Examing Evidence-Based Interventions to Prevent Inpatient Falls. Retrieved február 1, 2019, from Medsurg Nursing: https://search.proquest.com/openview/3983639563e2cee00df8f6d830719370/1?pqorigsite $=$ gscholar $\& \mathrm{cbl}=30764$

Gray-Micelli, D., \& Quigley, P. A. (2012, August). Nursing Standard of Practice Protocol: Fall Prevention. Retrieved from The Hartford Institute for geriatric nursing: https://consultgeri.org/geriatric-topics/falls

Haines, T. P., Bennell, K. L., Osborne, R. H., \& Hill, K. D. (2006, July 13). A new instrument for targeting falls prevention interventions was accurate and clinically applicable in a hospital setting. Journal of Clinical Epidemiology, pp. 168-175.

Hughes, R. G. (2008, March). Patient safety and quality: An evidence-based handbook for nurses. Retrieved from Agency for Healthcare Research and Quality, AHRQ Publication: http://citeseerx.ist.psu.edu/viewdoc/download?doi=10.1.1.182.7844\&rep=rep1\&type=pdf

Jurásková, D. (2007). Hospitalizace pacienta a jeho bezpečnost [Hospitalization of a patient and their safety]. Praha: EuroProfis.

Krajčík, Š. (2006). Pády a ich príčiny v starobe [Falls and their causes in old age]. Via Practica(7-8), 344-346.

Líšková, M., \& Starovičová, M. (2012). Mimoriadne udalosti ako aspekt starostlivosti. [Extraordinary events as an aspect of care]. Aspekty práce pomáhajících profesí. [Aspects for helping professions]. (pp. s. 185 - 194). Praha: Manus.

MHSR Ministry of Health of the Slovak Republic. (2018, March 12). Proclamation 95/2018 Z.z. MZ SR, which dictates the extent of nursing practice provided by the nurse alone, alone on the basis of a doctor's indication, and in cooperation with a doctor. Retrieved december 18, 2018, from Právne predpisy/Zbierka zákonov Slovenskej republiky: https://www.slovlex.sk/pravne-predpisy/SK/ZZ/2018/95/

Morse, J. M. (2002, June 30). Enhancing the safety of hospitalizacion by reducing pacient falls. American Journal of infection control, pp. 376-380.

NCSR National Council of the Slovak Republic. (2004, October 21). Zákon č. 578/2004 Z. z.Zákon o poskytovateloch zdravotnej starostlivosti, zdravotnickych pracovníkoch, ...... Act n. 578/2004 Z.z. Act about healthcare providers, nursing employees, professional healthcare organizations, and change acts. Retrieved 1 20, 2019, from Zákony pre l'udí: http://www.zakonypreludi.sk/zz/2004-578

Škrla, P. (2005). Především neubližit [Abova All No Harm]. Brno: Národní centrum ošetřovatelství a nelékařských zdravotnických oborů [National Center for Nursing and Non- medical Healthcare].

Šupínová, M. (2013). Komunitné ošetrovatel’stvo [Community Nursing]. Zvolen: Technická univerzita vo Zvolene [Technical University in Zvolen].

The Joint Commission . (2010). Implementation Guide for the NQF Endorsed Nursing-Sensitive Care Measure Set 2009. Retrieved from NSC Implementation Guide: https://www.jointcommission.org/assets/1/6/NSC\%20Manual.pdf

Ulrichová, K. (2012, May 5). Využivanie hodnotiacich nástrojov v starostlivosti o seniorov-diplomová práca [Usage of Assessment Tools in Elderly Care - Master Thesis]. Retrieved november 20, 2018, from Masarykova univerzita, Lekárska fakulta [Masaryk University, Faculty of Medicine]: http://is.muni.cz/th/381762/lf_m/Diplomova_praca._Katarina_Ulrichova.pdf 
Vörösová, G. (2011). Ošetrovatel'ský proces v internom ošetrovatel'stve [Nursing Process in Internal Nursing]. Martin: Osveta.

Vyhnánek, R. (2007). Prevence pádů ve zdravotnickem zařizení [Prevention of Falls in a Healthcare Facility]. Praha: Tlačiarne Havíčkův Brod.

World Health Organization. (2007, March 7). WHO Global Report on Falls Prevention in Older Age. Retrieved december 12, 2018, from World Health Organization - Ageing and Life Course, Family and Community Health:

https://www.who.int/ageing/publications/Falls_prevention7March.pdf 